\title{
EFEKTIFITAS APLIKASI SMARTCITY PADA PENGGUNA SMARTPHONE UNTUK MEWUJUDKAN KOTA NYAMAN UNTUK SEMUA DI KOTA MAKASSAR ${ }^{1}$
}

\author{
${ }^{1}$ Sartika Dwi Hardiyanti, ${ }^{2}$ Christine Andu Purnamasari \\ ${ }^{1}$ Jurusan Ilmu Politik, Fakultas Ilmu Sosial dan Ilmu Politik, Universitas Teknologi Sulawesi \\ (sartikadwihardiyanti@gmail.com) \\ ${ }^{2}$ Jurusan Ilmu Politik, Fakultas Ilmu Sosial dan Ilmu Politik, Universitas Teknologi Sulawesi \\ christine.andu@yahoo.com)
}

\begin{abstract}
ABSTRAK
Penekanan pembangunan smart city dalam mengatasi banyak masalah di tiap kota, baik kemacetan, keamanan warga kota, permasalahan sosial, sampai penumpukan sampah. Ide pembangunan smart city ditekankan dengan penggunaan teknologi dan informasi dalam kehidupan sehari-hari diharapkan menjadikan kota dapat melayani warga dan menghadirkan solusi bagi permasalahan daerah. Penelitian ini bertujuan untuk menganalisis besarnya efektifitas output aplikasi smart city pada pengguna smartphone dalam terwujudnya kota nyaman untuk semua sesuai visi Kota Makassar, menganalisis sejauhmana aplikasi smart city dapat membantu dan diakses oleh masyarakat dengan mudah. Populasi dalam penelitian ini adalah masyarakat Kota Makassar pengguna smartphone, dengan metode penarikan sampel yang digunakan adalah Pengambilan sampel dalam penelitian ini dilakukan dengan metode purposive sampling, Sampel yang dimaksud dalam penelitian ini adalah masyarakat kelas menengah yang ada di Kota Makassar. Melihat efektifitas aplikasi smart city dalam mewujudkan kota nyaman untuk semua di kota Makassar. Pada penelitian ini peneliti melihat visi Kota Makassar menjadikan kota nyaman untuk semua dengan konsep smart city. Meninjau aplikasi smart city sebagai wadah penyampaian permasalahan umum dan sosial masyarakat kota Makassar. Hasil penelitian menunjukkan bahwa aplikasi smartcity kota Makassar sangat efektif terhadap pengguna smart phone di kota Makassar, yakni penggunaan smart rt/rw yang dapat membantu kinerja rt/rt di Kota Makassar, aplikasi kucataki dapat membantu masyarakat Kota Makassar dalam mengisi formulir pembuatan akte kelahiran dan akte kematian sebelum mencetak di Kantor Catatan Sipil Kota Makassar, aplikasi layanan 112 salah satunya layanan homecare dengan pelayanan kesehatan dirumah warga, aplikasi Warroom meninjau Kota Makassar dalam satu layar. Efektifitas aplikasi smartcity pada pengguna smart phone Kota Makassar langsung dapat dirasakan oleh warga Kota Makassar.
\end{abstract}

Kata Kunci: Efektifitas, Aplikasi Smartcity, Pengguna Smartphone, Untuk Mewujudkan Kota Nyaman untuk Semua, Kota Makassar.

\footnotetext{
${ }^{1}$ Versi preprint naskah yang sedang dalam proses penerbitan di The Politics: Jurnal Magister Ilmu Politik Universitas Hasanuddin (http:// journal.unhas.ac.id/index.php/ politics/ index). Submission ID: 7603.
} 


\section{PENDAHULUAN}

Masyarakat pada umumnya tidak terlepas dari keadaan sosial yang terjadi dalam kehidupan, sebab masyarakat adalah zoon politicon atau masyarakat sosial yang saling berhubunganantarasatudenganyanglaindansalingberinteraksiuntukmencapai tujuan hidup. Masyarakat Indonesia merupakan masyarakat yang komplek yakni masyarakat yang berkembang seiring dengan perkembangan zaman, baik dalam pedesaan maupun perkotaan.Kini masyarakat Indonesia memiliki pola pikir masyarakat yang rasional yang bersumber dari perkembangan teknologi itu sendiri sehingga kepercayaan serta spritualisme semakin memudar.

Seiring bertambahnya penduduk Indonesia dari tahun ke tahun membuat kondisi masyarakat Indonesia juga semakin komplek.Keadaan ini membuat pemerintahan Indonesia mengeluarkan konsep smart city untuk membangun Indonesia kedunia modern dan maju dalam perekonomian.Saat ini banyak Kota/Kabupaten berlomba- lomba membangun konsep smart city. Konsep pembangunan kota dengan pengedepanan smart city sedang menjadi program pembicaraan beberapa kota besar di Indonesia. Salah satunya adalah Kota Makassar yang menjadikan konsep smart city menjadi program pemerintahan daerah kota Makassar menuju kotacerdas.

Pembangunan berbasis Smart City menyediakan ruang inovasi yang luas untuk menyelesaikan berbagai persoalan yang dihadapi oleh pemerintah daerah, masyarakat, pelaku bisnis, dunia pendidikan dan berbagai pemangku kepentingan (stakeholder) lain. Visi Kota Makassar yaitu Makassar Kota Dunia yang Nyaman Untuk Semua, dimana dari potensi ini menjelma menjadi Kota yang sejajar dengan kota-kota di Dunia, dan bahkan memberikan dampak pertumbuhan ekonomi tertinggi serta dampak multipaleyer efek bagi usaha jasa, usaha kreatif, pendidikan dan sector pendukung lainnya. Namun semua potensi-potensi yang telah dijelaskan diatas, permasalahan Kota Makassar sudah berkembang sangat kompleks sehingga diperlukan solusi-solusi yang lebih inovatif (smart city) untuk menyelesaikan masalah kota. Kota Makassar mengeluarkan aturan dalam bentuk aplikasi smart city yakni salah satunya berupa produk aplikasi smart rt/rw dan layanan 112, yang dapat diakses oleh masyarakat Kota Makassar untuk menyampaikan permasalahannya dan opininya mengenai layanan umum 
maupun masalah sosial. Meskipun demikian, Smart city merupakan sebuah konsep yang memiliki kelebihan dan kekurangan.

Oleh karena itu, dengan penjelasan diatas maka peneliti mengangkat judul penelitian yakni "Efektifitas Aplikasi Smartcity Pada Pengguna Smartphone Untuk Mewujudkan Kota Nyaman Untuk Semua Di Kota Makassar”

Permasalah yang diteliti yakni melihat sejauhmana efektifitas masyarakat pengguna smartphone pada aplikasi smart city dalam mewujudkan Kota Makassar kota nyaman untuk semua?.

Tujuan Penelitian yakni mengukur tingkat efektif penggunaan aplikasi smart city dalam menyapaikan dan mencari solusi permasalahan masyarakat di Kota Makassar, agar visi Kota Makassar yang nyaman untuk semua dapat teralisasi.

Urgensi penelitian yakni Permasalahan layanan umum dan permasalahan sosial di Kota Makassar diperlukan strategi dan pendekatan yang komprehensif, inklusif, efektif dan efisien.Kini Kota Makassar mengeluarkan aturan sebuah aplikasi bagi masyarakat untuk dapat menyampaikan, melaporkan, dan melihat perkembangan keadaan Kota Makassar dalam layar smartphone masing-masing.Semakin banyak aturan yang dibuat, maka semakin kompleks permasalahan yang ada dimasyarakat. Sehingga dapat ditinjau seberapa jauh efektifitas aplikasi smart city pada pengguna smartphone untuk mewujudkan kota nyaman untuk semua di KotaMakassar.

\section{Tinjauan Pustaka}

\section{Teori Smart City}

Secara harfiah smart city yakni kota pintar, merupakan suatu konsep pengembangan, penerapan, dan implementasi teknologi yang diterapkan disuatu daerah sebagai sebuah interaksi yang kompleks di antara berbagai sistem yang ada di dalamnya. Tujuan dari pendekatan smart city untuk mencapai informasi dan pengelolaan kota yang terintegrasi. Integrasi ini dapat melalui manajemen jaringan digital geografi perkotaan, sumber daya, lingkungan, ekonomi, sosial danlainnya. Kota cerdas atau smart city, pada umumnya didasarkan pada 3 hal, pertama faktor manusia, kota dengan manusia-manusia yang kreatif dalam pekerjaan, jejaringpengetahuan, lingkungan yang bebas dari kriminal. Kedua faktor teknologi, kota yang berbasis teknologi komunikasi dan informasi. Terakhir faktor kelembagaan, masyarakat kota 
(pemerintah,kalangan bisnis dan penduduk) yang memahami teknologi informasi dan membuat keputusan berdasarkan pada teknologi informasi.

Pada intinya konsep smart city adalah bagaimana cara menghubungkan infrastruktur fisik, infrastruktur sosial dan infrastruktur ekonomi dengan menggunakan teknologi ICT, yang dapat mengintergrasikan semua elemen dalam aspek tersebut dan membuat kota yang lebih efisien dan layak huni.

\section{Aplikasi Smart City}

Kota Makassar merupakan salah satu kota metropolitan, untuk mewujudkan visi Kota Makassar kota nyaman untuk semua, pemerintahan Kota Makassar membuat program- berbasis teknologi antara lain [5]:

Puskesmas digital (layanan 112) adalah Makassar Home Care, layanan kesehatan yang menyasar rumah warga. Jika membutuhkan layanan kesehatan di rumah, warga tinggal menghubungi call center 112, selanjutnya call center akan menghubungi puskesmas terdekat agar segera mengirimkan tim 'Dottoro'ta (dokter kita) ke rumahpasien.

War Room yang merupakan ruang operasional pemerintahan Kota Makassar untuk memerangi masalah-masalah di masyarakat. Pemerintahan Kota Makassar dapat memantau kegiatan seisi kota melalui 115 CCTV yang tersebar di lokasi-lokasi strategis dari dalamruangan.

Smart RT/RW atau Makassar smart city merupakan aplikasi yang digunakan masyarakat untuk dapat menyampaikan permasalahan umum dan sosial pada laman yang telah disediakan dalam aplikasi tersebut. Dikhususkan pula pada ketua RT/RW yang telah dibuatkan aplikasi smartphone, untuk dapat melaporkan langsung permasalahan lokasi/daerahnya, dimana dapat ditinjau lansung oleh Walikota Makassar dan masyarakat kota Makassar. Dimana aplikasi ini dapat diperoleh oeh pengguna smartphone dengan mengunduhnya pada aplikasi playstore.

\section{Teori Smartphone}

Smartphone adalah telepon selular dengan mikroprosesor, memori, layar dan modem 
bawaan. Smartphone merupakan ponsel multimedia yang menggabungkan fungsionalitas PC dan handset sehingga menghasilkan gadget yang mewah, di mana terdapat pesan teks, kamera, pemutar musik, video, game, akses email, tv digital, search engine, pengelola informasi pribadi, fitur GPS, jasa telepon internet dan bahkan terdapat telepon yang juga berfungsi sebagai kartu kredit.

Manfaat Smartphone bagi Masyarakat:

1. Komunikasi AntarManusia.

Smartphone seseorang dapat melakukan komunikasi seperti handphone biasa pada umumnya, yaitu seperti untuk telepon suara, mengirim pesan sms, pesan mms, dan layanan data.

2. MencariInformasi/Ilmu

Smartphone dengan segala sistem canggih di dalamnya juga berubah fungsi dengan hadirnya kemampuan akses informasi.Masyarakat dapat menemukan beragam jawaban dari berbagai bidang masalah dengan memanfaatkan dunia maya melalui smartphone.

3. Hiburan

Smartphone dapat menayangkan berbagai format multimedia yang ada.

4. Aplikasi

Pengguna hape smartphone dapat memasang dan menjalankan berbagai aplikasi yang tersedia di internet dan juga non internet yang sesuai dengan sistem operasi yang digunakannya.

5. PenyimpananData

Kapasitas memori smartphone yang besar bisa berfungsi sebagai media penyimpanan data file. Seperti halnya usb flashdisk, usb external drive dan multimedia card, handphone yang canggih pun dapat dipergunakan untuk meletakkan berbagai file sesuai dengan kapasitas yang ada pada smartphone.

6. Gaya

Banyak masyarakat yang menggunakan handphone smartphone untuk menunjang penampilan sehari-hari.

7. PenunjukArah 
Salah satu fungsi penting dari smartphone adalah untuk mendapatkan informasi arah mata angin, arah kiblat, dan lain sebagainya.Smartphone yang memiliki fasilitas GPS dapat menunjukkan arah mata angin seperti layaknya kompas sungguhan.Selain itu dengan dipadukan layanan jejaring sosial maka dapat menjadi sesuatu yang sangat menarik dan dibutuhkan.

\section{VISI DAN MISI RPJMD 2014- 2019}

Berdasarkan analisis terhadap permasalahan pembangunan dan isu strategis daerah Kota Makassar dengan memperhatikan sepenuhnya visi kepala daerah terpilih, maka Visi Pemerintah Kota Makassar 2014-2019 adalah: "Makassar Kota Dunia yang Nyaman

\section{UntukSemua"}

Visi Pemerintah Kota Makassar 2014- 2019 memiliki konsistensi dengan visi Kota Makassar 2005-2025, khususnya pada penekanan "orientasi global", dalam RPJMD dirumuskan sebagai "kota dunia". Penekanan "berwawasan lingkungan" dan "paling bersahabat" pada visi dalam RPJPD dirumuskan sebagai "yang nyaman untuk semua" pada visi dalam RPJMD 2014-2019. Pokok visi "kota maritim, niaga, pendidikan, budaya dan jasa” pada visi dalam RPJPD, pada visi dalam RPJMD 2014- 2019 ditempatkan sebagai bagian dari substansi "kota dunia". Dihubungkan dengan visi Pemerintah Provinsi Sulawesi Selatan 2018, relevansi visi Pemerintah Kota Makassar 2014-2019 terletak pada posisi "Makassar kota dunia yang nyaman untuk semua" yang merupakan bagian penting dari terwujudnya "Sulawesi Selatan sebagai Pilar Utama Pembangunan Nasional dan Simpul Jejaring Akselerasi Kesejahteraan pada Tahun 2018”.

Pernyataan visi Pemerintah Kota Makassar 2019 memiliki tiga pokok visi yang merupakan gambaran kondisi yang ingin dicapai Kota Makassar pada akhir periode 20142019 [5]. Penjelasan masing-masing pokok visi tersebut, adalah sebagai berikut.

Kota Dunia, dimaksudkan adalah Kota Makassar yang memiliki keunggulan komparatif, kompetitif,aksesibel daninklusifitas yang berdayatarik tinggi atau memukau dalam banyak hal. Diantaranya potensi sumberdaya alam dan infrastruktur sosial ekonomi yang menjanjikan terwujudnya kesejahteraan masyarakat dengan standar dunia.Pokok visi ini dapat dikristalkan sebagai terwujudnya "masyarakat sejahtera standar dunia".

Nyaman, dimaksudkan adalah terwujudnya proses pembangunan yang semakin 
menyempitkan kesenjangan dan melahirkan kemandirian secara stabil, dalam struktur dan pola ruang kota yang menjamin kenyamanan dan keamanan bagi berkembangnya masyarakat yang mengedepankankan prinsip inklusifitas serta pola hubungan yang setara antara stakeholder danstakeowner dalam pembangunan. Pokok visi ini dapat dikristalkan sebagai terwujudnya "kota nyaman kelas dunia".

Untuk Seтиa, dimaksudkan adalah proses perencanaan, pelaksanaan dan pemanfaatan pembangunan yang dapat dinikmati dan dirasakaan seluruh lapisan masyarakat tanpa diskriminasi berdasarkan jenjang umur, jenis kelamin, status sosial dan kemampuan diri (termasuk kelompok disabilitasl). Pokok visi ini dapat diristalkan sebagai terwujudnya "pelayanan publik standar dunia dan bebas korupsi”.

\section{BAHAN DAN METODE PENELITIAN}

\section{Pendekatan dan Jenis Penelitian}

Metode penelitian yang digunakan dalam penelitian ini menggunakan metode kualitatif.Metode atau model pendekatan kualitatif adalah prosedur penelitian yang menghasilkan data deskriptif berupa kata-kata tertulis maupun lisan dari orang-orang dan aplikasi smartcity yang diamati.Metode kualitatif digunakan untuk mendapatkan data yang mendalam, suatu data yang mengandung makna. Makna adalah data yang sebenarnya, data yang pasti yang merupakan suatu nilai di balik data yang tampak. Oleh karena itu dalam penelitian kualitatif tidak menekankan pada generalisasi, tetapi lebih menekankan pada makna.

\section{Lokasi Penelitian}

Lokasi penelitian berada di wilayah Kota Makassar dengan memusatkan pada pemukiman rt/rw di Kota Makassar, Puskesmas di Kota Makassar, Catatan Sipil Kota Makassar, dan Dinas Komunikasi dan Informasi Kota Makassar (Diskominfo Makassar).

\section{Pengumpulan Data}

Pengumpulan data dalam penelitian ini dimulai dengan cara mengumpulkan sumbersumber kepustakaan, melalui : (1) penulis mengumpulkan data-data yang diperlukan dengan cara melakukan wawancara mendalam yang bersifat terbuka maupun wawancara bebas dengan 
beberapa nara sumber yang cukup memahami dan mengetahui tentang permasalahan yang dibahas (2) penulis dalam mengumpulkan data yang berkaitan dengan objek penelitian berusaha mendokumentasikan semua data dan informasi yang diperoleh dilapangan, hal ini ditujukan untuk lebih memudahkan melihat permasalahan yang terjadi sebelumnya dengan menganalisa data yang didokumentasikan (Rossman, 2007). Selain itu mengetahui lebih mendalam suatu masalah berdasarkan data.

\section{Analisis Data}

Dalam penelitian kualitatif ini penulis mengunakan teknik analisis deskriftif kualitatif untuk menganalisis berbagai data dan informasi yang diperoleh dilapangan yang dilakukan melalui tiga kegiatan dan terjadi secara bersamaan yaitu reduksi data, sajian data dan penarikan kesimpulan (Kaelan, 1990).Penggunaan teknik analisis kualitatif ini bertujuan untuk mengambarkan secara riil dari berbagai masalah yang terjadi.

\section{HASIL PENELITIAN}

\section{Efektifitas Smartcity Kota Makassar Pada Pengguna Smartphone}

Pemerintah Daerah melalui inovasi dalam UU No. 23 Tahun 2014 tentang Pemerintahan Daerah.Dalam Bab XXI bertajuk Inovasi Daerah. Dari Pasal 386 hingga Pasal 390 UU 23/2014, menjelaskan bahwa dalam rangka peningkatan kinerja penyelenggaraan Pemerintahan Daerah, Pemerintah Daerah dapat melakukan inovasi. Inovasi sebagaimana dimaksud adalah semua bentuk pembaharuan dalam penyelenggaraan Pemerintahan Daerah. Dalam merumuskan kebijakan inovasi, Pemerintahan Daerah mengacu pada prinsip: peningkatan efisiensi; perbaikan efektivitas; perbaikan kualitas pelayanan; tidak ada konflik kepentingan; berorientasi kepada kepentingan umum; dilakukan secara terbuka; memenuhi nilai-nilai kepatutan; dan dapat dipertanggungjawabkan hasilnya tidak untuk kepentingan diri sendiri.

Membangun Kota Makassar dengan menerapkan konsep smart city memerlukan pendekatan yang komprehensif yang terintegrasi kedalam satu kesatuan (sistem), dengan satu tujuan pokok, yakni melayani semua kebutuhan masyarakat dengan cepat, tepat, ramah dan memuaskan, dengan bertumpu pada pemanfaatan teknologi informasi secara maksimal.

Pemanfaatan konsep manajemen strategi dalam membangun Makassar Smart City memberikan pedoman yang sangat jelas terhadap langkah-langkah strategis dalam pembangunan 
Makassar Smart City sehingga segala sesuatunya akan teridentifkasi dengan jelas dan diharapkan tingkat keberhasilan sangat besar. Salah satu sasaran Smart City Kota Makassar adalah sasaran Smart Governance Kota Makassar, yakni tata kelola pemerintahan yang efiensi, terintegrasi, berkinerja tinggi, bebas korupsi, inovatif, komunikatif melalui inovasi yang smart, terintegrasi dengan sistem jaringan data terpusat, platform one data, dan sistem keamanan dan berasuransi. Smart Governance harus dapat diimplementasikan ke dalam tiga unsur dalam tata kelola, yakni pelayanan (service), birokrasi (bureaucracy), dan kebijakan (policy). Hal inilah yang menggambarkan aplikasi smart rt/rw, war room, layanan 112 dan aplikasi kucataki muncul dan dapat digunakan oleh masyarakat.

Sasaran smart cityKota Makassaryang meliputi tingkatan manajemen Kota yang terintegrasi dan efisien dengan menggunakan ICT (public servis) yakni:

- Terlaksanananya pelayanan public terintegrasi untuk mencapai layanan yang efektif, efisien, transparan.

- Adanya peningkatan pelayanan terpadu di kelurahan dan kecamatan

- Pengembangan akses internet pada ruang publik

- Aksesibilitas pelayanan oleh semua lapisan masyarakat termasuk berkebutuhan khusus (difabel).

- Pengawasan dan pengamatan masyarakat melalui media sosial yang terkoneksi dengan unit layanan publik.

- Pembangunan infrastruktur dalam rangka mengintegrasikan seluruh layanan, baik melaui sistem online atau melalui musrembang disetiap SKPD dalam perencanaan dan perumusan kebijakan

- Pengembangan aplikasi e-gov harus diarahkan menuju integrated \& inter-operability egov atau yang saling berkomunikasi dan terhubung antar satu aplikasi dengan aplikasi lainnya serta lintas OPD atau yang disebut dengan Smart e-Gov. Pelayanan Smart e-Gov ini perlu didukung dengan sebuah "City Operation Center (COC)".

- Pelaksanaan dan pengawasan implementasi standar operasional pelayanan bagi setiap level birokrasi

- Peningkatan etos dan kinerja pemerintah daerah hingga RT/RW

- Birokrasi yang bersih, melayani dan berintegritas.

- Data Center yang terintegrasi ke semua SKPD Se Kota Makassar. 
- Optimalisasi TIK dalam pengelolaan manajemen birokrasi.

- Pengelolaan Anggaran Kota yang Kredible dan Transparan melalui sistim Online.

- Memudahkan masyarakat dalam memperoleh/mengakses layanan dokumen layanan perizinan, data kependudukan, dokumen perencanan, dan dokumen lainnya

- Mengembangkan brand kota melalui kegiatan promosi berkala dan pengembangan produk berciri lokal serta memiliki unsur kreatifitas dan inovasi yang kuat.

- Mewujudkan lingkungan tempat tinggal yang layak ditinggali, nyaman, aman dan efisien dan menjadikan Makassar sebagai kota untuk semua

- Membangun layanan informasi tata ruang digital

- Adanya standardisasi dan terintegrasi dalam pembangunan wilayah

- Penukaran sampah dengan kebutuhan masyarakat

$\checkmark$ Pembangunan perumahan murah seperti program Aparong (Apartemen Lorong)

$\checkmark$ Pengembangan pinggiran kota

$\checkmark$ Penataan Lorong

$\checkmark$ pengembangan infrastruktur kota yang aksesibel

$\checkmark$ Pengembangan vertical garden untuk lingkungan sempit perkotaan

- Tersedia ruang terbuka hijau, ruang ramah anak dan ruang laktasi disetiap tempat pelayanan public

- Menyediakan sistem pelayanan kesehatan yang berkualitas tinggi

- Mengintegrasikan layanan kesehatan dengan eWarga

- Membangun sistem kunjungan kesehatan terintegrasi antara warga dengan dokter ahli serta layanan kesehatan lainnya

- Manjakan LANSIA

- Membangun system keamanan yang kolaboratif dan didukung teknologi

- Mengimplementasikan elemen cerdas dalam setiap publik CCTV untuk mewujudkan Smart Monitoring

Pada dasamya dimensi sebuah Smart City, interaksi antar manusia telah bergerak menuju ekosistem sosio-teknis di mana dimensi fisik dan virtual dari kehidupan warga kota semakin terjalin secara intensif. Interaksi antar-warga terjalin dengan semakin kuat dan tanpa sekat dengan mediasi teknologi. 
Analisis hasil penelitian yang dilakukan menunjukkan kemajuan dalam implementasi konsep Smart City Kota Makassar.Aplikasi yang diciptakan untuk membantu kinerja pemerintahan dan keberlansungan hidup layak masyarakat Kota Makassar terlihat pada konsep aplikasi yang disajikan.

Aplikasi Smart RT/RW yang dibuat sebagai Aplikasi yang dikhususkan kepada RT dan RW sebagai pengguna utama, dan masyarakat sebagai pengguna umum sebagai media pelaporan kondisi lokasi tinggal dengan 9 indikator yang telah ditetapkan.Aplikasi yang dikhususkan kepada RT dan RW sebagai pengguna utama, dan masyarakat sebagai pengguna umum sebagai media pelaporan kondisi lokasi tinggal dengan 9 indikator yang telah ditetapkan, yakni : [1] lorong garden, [2] Makassar Ta' Tidak Rantasa' [3] Bank Sampah, [4] Retribusi Sampah, [5] Pajak Bumi dan Bangunan [6] Sombere' [7] Smart City [8] Administrasi RT/RW [9] Control Social Activity.

Layanan 112 homecare Kota Makassar layanan darurat bagi masyarakat Kota Makassar.Layanan 112 merupakan layanan bebas pulsa, layanan ini bisa diakses baik pengguna ponsel maupun telepon rumah.Termasuk saat ponsel tidak memiliki pulsa, bahkan ponsel dalam situasi terkunci. Apapun jenis provider seluler kita, 112 tetap bisa diakses secara gratus setiap saat selama 24 jam penuh. Pemanfaatan layanan 112 yakni [1] layanan mobil homecare [2] permintaan layanan Dinas PU, PLN, posko pohon tumbang, polisi, PDAM, ambulance, pemadam kebakaran, kebersihan, layanan sosial, PD parker dan layanan rumah sakit umum daerah. Warga tidak perlu lagi mengingat puluhan nomor layanan public yang tersedia, cukup menghubungi 112, maka semua kebutuhan layanan public bisa didapatkan. Masyarakat dapat melakukan pengaduan, dan aduan akan diteruskan kepada instansi maupun lembaga bersangkutan. Adapun aduan yang bisa disampaikan antara lain permintaan mobil kesehatan tujuan, banjir, kebakaran, kecelakaan, kesehatan, criminal, bencana alam, gangguan keamanan dan ketertiban, serta kerusuhan. Layanan 112 telah didukung oleh perangkat tekhnologi terbaru, sumber daya manusia terlatih, serta sistem integrasi dengan seluruh organisasi perangkat daerah di kota Makassar, Polisi dan perangkat keamanan lainnya yang bekerja 24 jam nonstop, sehingga masyarakat dengan mudah mendapatkan pelayanan yang diinginkan secara cepat. Konsep layanan kesehatan Home Care atau lebih dikenal dengan layanan Dottorotta 112 adalah layanan kesehatan dirumah, dengan mengobati pasien dirumah, apabila terpaksa membawa pasien ke puskesmas atau rumah sakit terdekat dengan ambulance home care. Nomor layanan 112 
tersambung dengan War Room Pemerintahan Kota Makassar. Integrasi layanan 112 dilakukan agar tim menghubungi layanan kesehatan home care terdekat dan segera mengirimkan tim yang terdiri dari dokter, perawat, dan sopir ke rumah pasien, semua dilakukan dan didapatkan secara gratis melalui program Smart City Kota Makassar. Layanan kesehatan home care yang dimaksud yakni penampilan petugasyangtim medis yang datang ke lokasi pengguna layanan, obat-obatan dan peralatan standar yang digunakan, dan tim medis yang profesional saat memberikan pelayanan.

Aplikasi Kucata'ki yakni merupakan aplikasi pelaporan kependudukan berbasis Android.Aplikasi Kucata'Ki merupakan software pelaporan kelahiran dan kematian serta pelaporan data kependudukan bebasis android dapat diunduh melalui Playstore. Dinas Kependudukan dan Catatan Sipil (Disdukcapil) Kota Makassar mengeluarkan Aplikasi Pelaporan Kependudukan Berbasis Android Inovasi Disdukcapil Makassar, Pencatatan Kelahiran, Kematian dan Pengaduan Dinas Kependudukan dan Pencatatn Sipil Kota Makassar, Dimana Masyarakat dan instansi yang berwenang (Puskesmas, RSIA, Kelurahan) dimudahkan dalam melakukan pendafataran kelahiran, pelaporan kematian serta Pengaduan Layanan Pada Dinas Kependudukan dan Pencatatan Sipil Kota Makassar.

War room adalah teknologi Kota Makassar, teknologi yang terkoneksi dengan 300 CCTV dalam Kota Makassar selama 24jam.War room memiliki fitur yang menyajikan kualitas gambar yang tajam dan daya jangkaunya relatif panjang hingga $4 \mathrm{~km}$ yang dapat difungsikan untuk mengontrol keamanan Kota Makassar sekaligus pelayanan public dan program Smart city Kota Makassar.War room dapat memonitoring perjalanan titik demi titik. War room bersinergi pada layanan pengaduan 112, dimana teknologinya memiliki kamera infra merah, dan dapat berputar 180 derajat. Kemampuan menyimpan data rekaman mampu hingga 5 tahun lamanya.Selain itu pula, War room ini juga menampilkan data kependudukan, pemantauan cuaca dan iklim, serta aplikasi tracking GPS pada semua kendaraan layanan publik milik Pemerintahan Kota Makassar. 


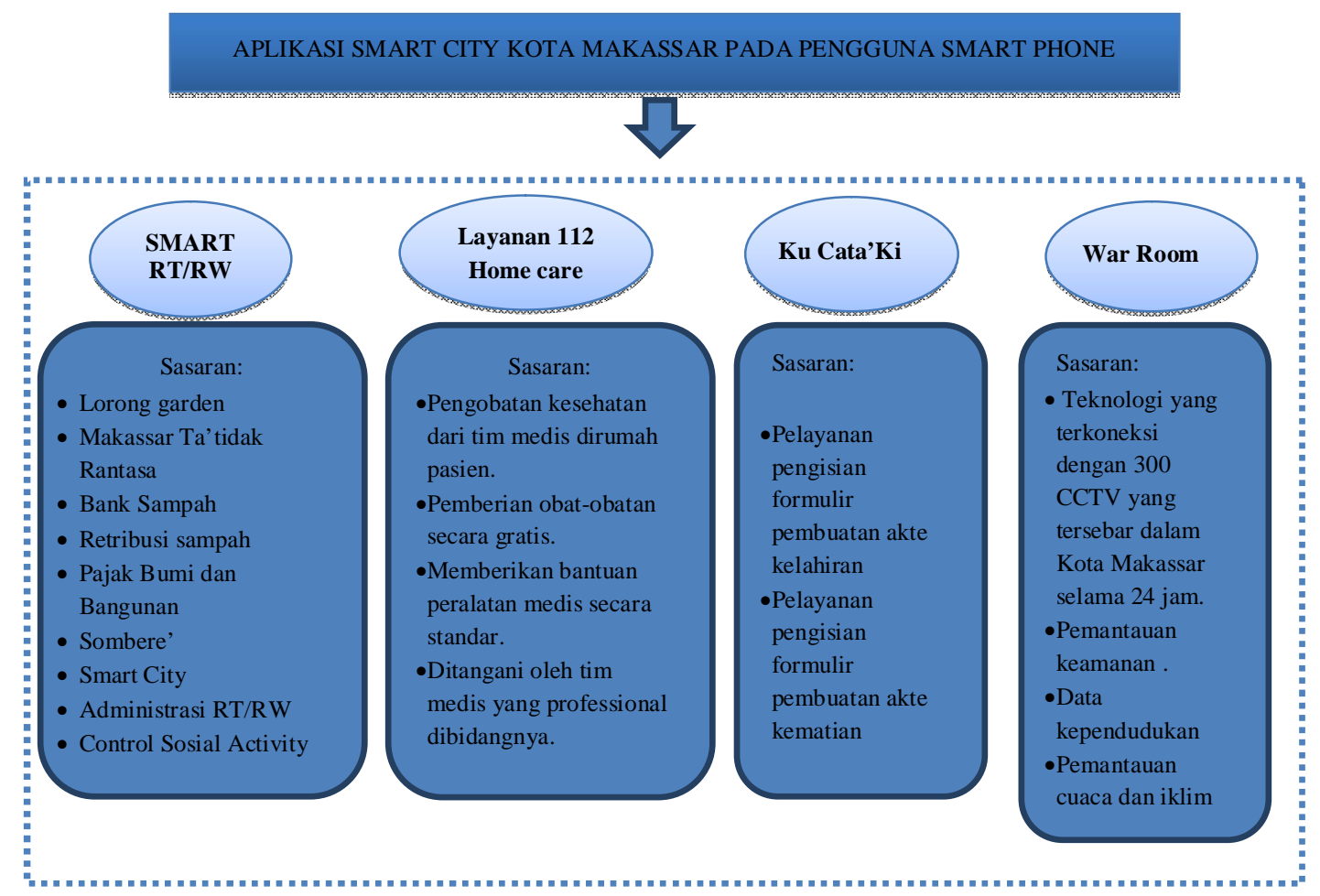

Gambar 1. Sasaran Aplikasi Smart City Kota Makassar pada Pengguna Smart Phone Sumber : Masterplan Smartcity Kota Makassar

\section{PEMBAHASAN}

Diukur dari informasi pelayanan yang diberikan sesuai dengan yang dijanjikan, pelayanan yang baik dan memberikan kepuasan bagi pengguna layanan dan yang terakhir yaitu pelayanan yang diberikan sesuai dengan harapan pengguna layanan. Adapun pelayanan yang baik dan memberikan kepuasan bagi pengguna layanan dapat dilihat dari limaindikator efektivitas pelayanan. Dimana dari hasil olahan data SPSS, menunjukkan bahwa masyarakat puas dengan pelayanan yang diberikan, yakni dari segi kehandalan, ketanggapan, jaminan, empati dan bukti fisik dari media layanan.Begitu juga dengan informasi layanan yang diberikan sudah sesuai dengan pelayanan yang diterima oleh pengguna layanan.

Masyarakat sebagai penerima layanan merupakan subjek yang dapat menentukan jenis, proses, dan kualitas layanan yang akan diperolehnya. Partisipasi masyarakat dalam penyelenggaraan pelayanan publik merupakan hak dan tanggung jawab masyarakat untuk mewujudkan penyelenggaraan pelayanan yang bersih.

Pemerintahahn kota Makassar merupakan salah Kota yang mendapatkan prestasi dalam bidang pelayanan berbasis ICT (Information Comunication Of Tekhnology). Terbukti dengan 
adanya aplikasi War Room yang dimiliki Kota Makassar serupa dengan Command Room yang ada di Markas Pertahanan AS di Pentagon. Aplikasi Home Care pelayanan langsung kerumah pasien, yang ditangani oleh tim medis professional. Aplikasi Kucata'Ki dengan pelayanan media yang memudahkan pendaftaran akte kelahiran dan kematian tanpa perlu mendatangi atau melakukan antrian di Kantor Catatan Sipil Kota Makassar. Aplikasi Smart RT/RW yang dipantau langsung oleh Walikota Makassar, SKPD Kota Makassar, dan warga Kota Makassar terhadap daerah bersih, aman, dan nyaman Kota Makassar.

Semua Aplikasi tersebut berjalan lancar sesuai tujuan dan sasaran aplikasi tersebut. Transformasi ke Kota Nyaman Untuk Semua mengacu pada proses mengubah kota menjadi kota yang cerdas, yaitu menggabungkan teknologi dan aplikasi cerdas untuk mengubah operasi dan pemberian layanan kepada masyarakat secara langsung.

\section{Layanan 112 Home Care Kota Makassar}

Layanan NTPD 112 merupakan Program dari Kementerian Kominfo RI Bekerja sama dengan Pemerintah Kota Makassar dimana Kota Makassar menjadi Pilot Project bersama 4 Kota Lainnya di Indonesia. Nomor Tunggal Panggilan Darurat (NTPD) layanan 112 merupakan layanan yang bisa diakses oleh warga Kota Makassar secara gratis untuk melaporkan situasi darurat seperti pengaduan home care, kebakaran, bencana alam, kemacetan, termasuk juga peristiwa criminal. NTPD layanan 112 Kota Makassar mempunyai kekuatan personil 33 orang setiap yang terbagi 3 dalam 24 jam sehari. Pelayanan NTPD 112 lebih popular dengan layanan home care atau lebih dikenal dengan layanan Dottorotta 112, dengan menelpon ke layanan 112 dan pengaduan mendapatkan layanan kesehatan dirumah, maka layanan 112 menyambungkan pada puskesmas terdekat dengan lokasi pasien, dan pasien akan ditangani oleh tim medis professional seperti dokter, perawat, bidan, ahli psikolog di lokasi pasien langsung. Apabila dibutuhkan obat-obatan tim medis akan memberikan obat-obat sebagai tindakan pertolongan pertama secara gratis, layanan home care juga menyediakan ambulance homecare apabila pasien harus dirujuk pada puskesmas atau rumah sakit terdekat. 

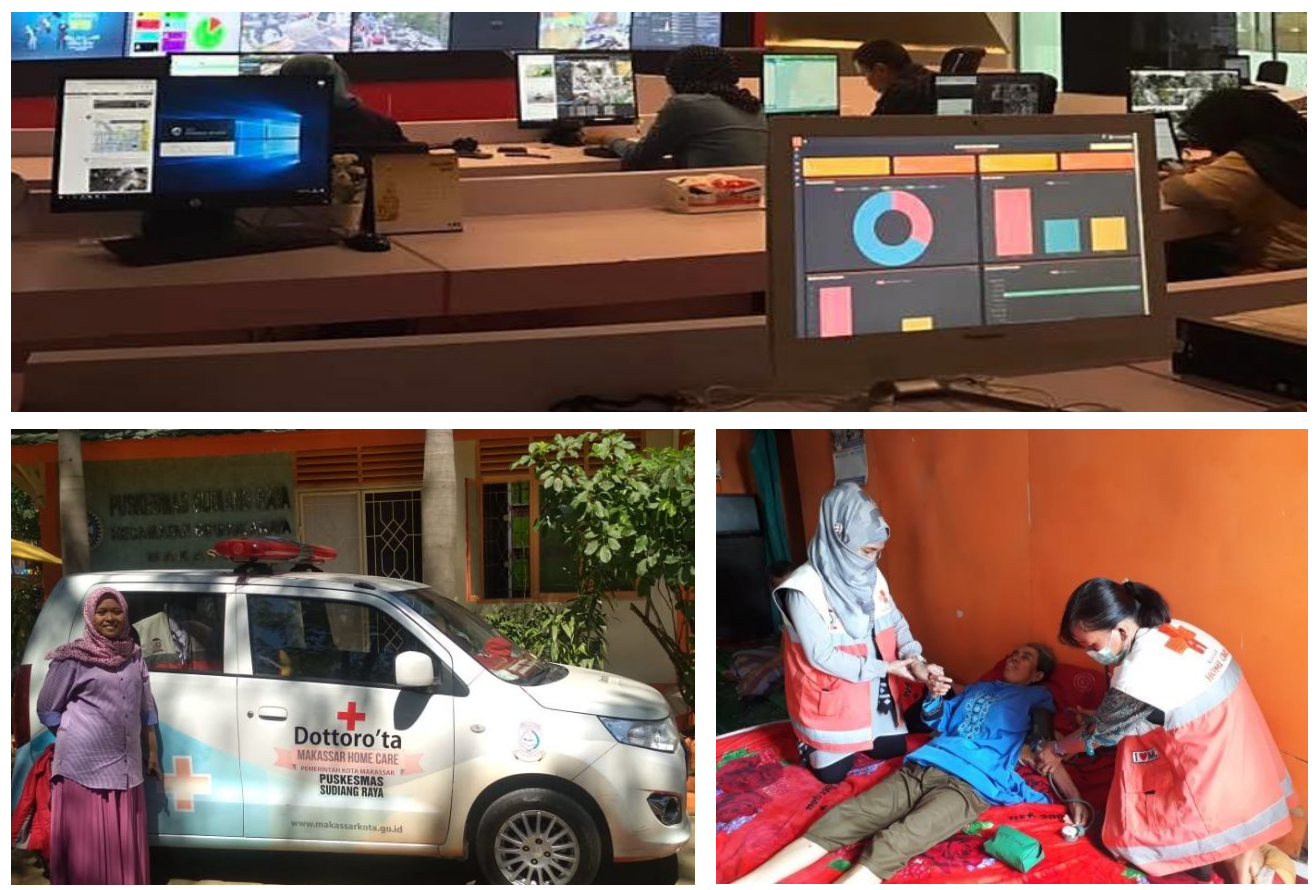

Gambar 2. Layanan NTPD 112 Home Care Kota Makassar Sumber: Dokumentasi Penelitian

\section{Layanan Smart RT/RW Kota Makassar}

Smart RT/RW adalah sistem informasi penunjang sekaligus sebagai indokator kinerja ketua RT/RW.Aplikasi smart RT/RW merupakan wadah bagi warga dan ketua RT/RW untuk melaporkan kondisi perkembangan wilayahnya untuk ditindak lanjuti oleh Pemerintahan Kota Makassar, utamanya terkait dengan penilaian Sembilan indicator yang diterapkan oleh Bagian Pemberdayaan Masyarakat (BPM) Sekretariat Kota Makassar.Namun dalam pengoperasian aplikasi Smart RT/RW hingga saat ini masih sulit untuk difungsikan secara maksimal.Salah satu ketua RT di kelurahan Masale Kecamatan Panakkukang Kota Makassar mengatakan bahwa: "saya sulit mengoperasikan aplikasi RT/RW dari awal saya dapatkan sangat susah untuk login kedalam aplikasi." Senada dengan hasil wawancara Ketua RT kelurahan Laikang Kecamatan Biringkanaya mengatakan bahwa "diawal pembuatan aplikasi ini saya selalu melaporkan kegiatan, keadaan lingkungan kelurahan saya, namun sejak pilkada tahun 2018 aplikasi ini seperti tidak bisa digunakan lagi, pelaporan yang dimasukkan tidak mendapat respon dari pemerintahan Kota Makassar, karena aplikasi ini tidak dapat digunakan lagi sehingga pelaporan saya sampaikan melalui aplikasi whatsapp group RT/RW Kota Makassar.Dinas Komunikasi da 
Informatika (Diskominfo) Makassar mengatakan bahwa pengguna aplikasi Smart RT/RW hingga saat ini sudah mencapai 9.998 pengguna (user) termasuk ketua RT/RW se Kota Makassar.Namun dalam kenyataan aplikasi ini masih sulit dioperasikan, "bila mana ada kendala dapat dilaporkan ke pengaduan layanan 112" himbau Kepala Bidang Pengembangan Aplikasi dan Telematika Diskominfo Kota Makassar.Dia menambahkan, hingga saat ini pihaknya telah menerima laporan perihal perbaikan aplikasi.Hanya saja, dia tidak mengetahui secara pasti jumlah laporan tersebut.
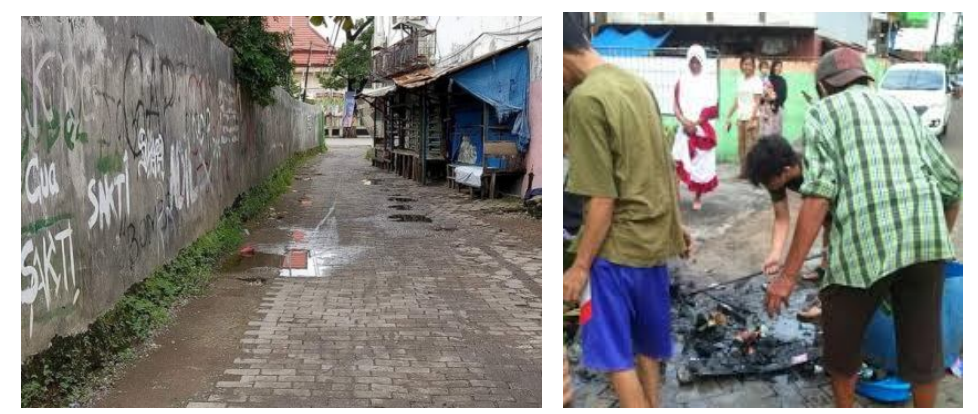

Gambar : Laporan warga dan RT/RW pada aplikasi Smart RT/RW Sumber : Dokumentasi Penelitian
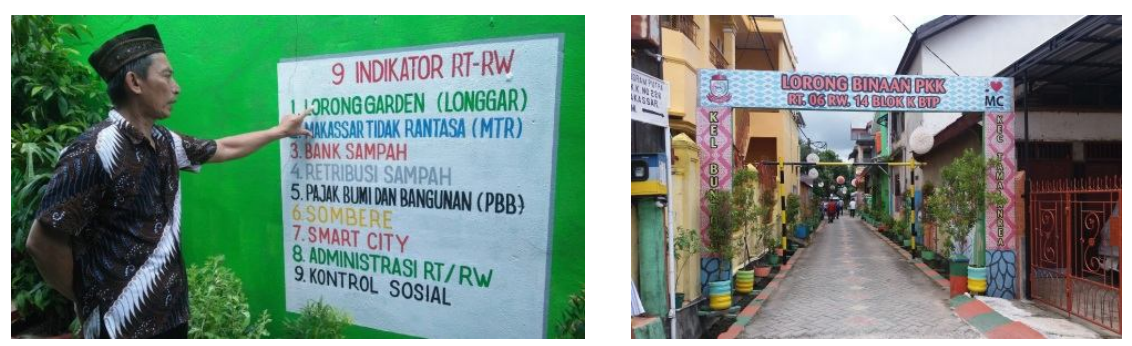

Gambar :Aplikasi Smart RT/RW Kota Makassar Sumber : Dokumentasi Penelitian

\section{KESIMPULAN DAN SARAN}

Makassar adalah kota terbesar di Indonesia Timur. Jika dilihat dari aspek pembangunan dan infrastruktur, Kota Makassar tergolong salah satu kota metropolitan di Indonesia. Melihat begitu banyaknya jumlah penduduk Kota Makassar serta menjamurnya pengguna ponsel pintar atau ponsel smartphone dengan berbagai media sosial didalamnya.Kota Makassar dalam program Smart City membuat sebuah ide aplikasi sebagai solusi untuk memudahkan aktivitas sosial, pelayanan dalam pemerintahan, dan pemantauan langsung kepada kinerja pemerintah Kota Makassar. Setelah melakukan survey dari beberapa aplikasi smart city, yaitu war room, layanan 112 home care atau dottorot'ta, aplikasi smart city rt/rw, aplikasi kucata'ki, maka 
kesimpulan yang ditemukan adalah aplikasi smart city pada pengguna smart phone memiliki fungsi terintegrasi satu sama lain dan membawa manfaat bagi kelangsungan hidup masyarakat Kota Makassar.

Program war room yang dibuat untuk memantau Kota Makassar dalam satu layar, dimana war room menjadi pusat menghubungkan SKPD di Kota Makassar dengan layanan cepat tanggap kota Makassar. Memantau disetiap kejadian sudut Kota Makassar. Memberikan informasi yang cepat dan dapat terekam 24 jam berlangsung, sehingga Kota Makassar memiliki pengontrol kota siaga.

Program layanan 112 home care atau dottoro'ta merupakan layanan kesehatan pertama dimakassar yang melayani pasien di rumah pasien, dengan menelpon ke layanan 112 dan dihubungkan pada layanan home care atau dottorot'ta. Layanan yang siaga dan ditangani oleh petugas kesehatan professional, pertolongan dengan tindakan medis memadai, pemberian obatobatan sesuai dengan penyakit pasien, pelayanan mobil ambulance merujuk ke Rumah Sakit Umum Daerah Daya Kota Makassar.

Aplikasi Smart RT/RW yang dirilis terkhusus kepada ketua rt/rw dalam pelaporan langsung kepada pemerintahan Kota Makassar dan Kepala daerah Kota Makassar.aplikasi smart $\mathrm{rt} / \mathrm{rw}$ ini sebagai penilaian insentif bagi ketua rt/rw Kota Makassar. Aplikasi ini juga dapat di akses oleh masyarakat umum Kota Makassar, dapat sebagai pengaduan, pemantauan, dan informasi perkembangan infrakstruktur Kota Makassar. Aplikasi smart rt/rw melayani dari 9 aspek layanan yakni lorong garden, Makassar Ta'tidak rantasa, bank sampah, retribusi sampah, pajak bumi dan bangunan, sombere', smart city, administrasi rt/rw, dan control social activity. Aplikasi kucata'ki merupakan software pelaporan kelahiran dan kematian serta pelaporan data kependudukan berbasis android. Dengan mengisi formulir kelahiran atau kematian di form pada aplikasi kucata'ki akan mendapatkan nomor registrasi pendaftaran, dan demikian bilamana telah memiliki nomor registrasi pendaftaran yang diambil setelah mengisi dan mengunggah berkas yang diperlukan maka nomor registrasi tersebut dalam digunakan dalam mengambil akta kelahiran maupun akta kematian di kantor catatan sipil Kota Makassar. 


\section{DAFTAR PUSTAKA}

Demirci, K., Akgonul, M,.\& Akpinar, A. (2015). Relationship of smartphone use severity with sleep quality, depression, and anxiety in university students. Jurnal of Behavioral Addictions $4(2), 85-92$.

Oktavia, V., 2014. Ubiquitous City dan Perkembangannya Menuju Smart City (Kasus: Kota Seoul). Penelitian.Yogyakarta : Universitas Gadjah Mada.

Pemerintah Kota Makassar, (2017). Buku II: Masterplan Smart City Daerah. Kota Makassar, Pemkot KotaMakassar

Widyaningsih, D., 2014. Kota Surabaya Menuju Smart City.Tesis. Yogyakarta: Universitas Gadjah Mada 